\title{
MODERNISMO PORTUGUÊS E MODERNISMO BRASILEIRO: QUE DIÁLOGO? ENTREVISTA A EDUARDO LOURENÇO
}

\author{
Madalena Vaz Pinto \\ (Universidade do Estado do Rio de Janeiro - \\ Faculdade de Formação de Professores )
}

\section{APRESENTAÇÃO}

A entrevista a Eduardo Lourenço que agora se apresenta foi realizada como complemento à minha tese de doutorado defendida em 2007 na Pontifícia Universidade Católica do Rio de Janeiro. Intitulada "Modernismos em língua desdobrada: Portugal e Brasil", a pesquisa pretendeu pensar as relações entre o modernismo português e brasileiro. Duas entrevistas foram feitas com o objetivo terminar o trabalho com uma reflexão, contemporânea, sobre esse importante e determinante movimento, uma a Eduardo Lourenço e outra a Silviano Santiago. A escolha de Eduardo Lourenço pareceu-me incontornável por se tratar de um autor com importantes reflexões sobre o período mas também, e talvez principalmente, pelo seu olhar desassombrado e tantas vezes crítico em relação à cultura portuguesa. Dessa entrevista selecionei as questões em que fica mais evidente a comparação entre os dois modernismos.

PALAVRAS-CHAVE: modernismo português e brasileiro, diálogo entre culturas, rasura. 


\section{MODERNISMO PORTUGUÊS E MODERNISMO BRASILEIRO}

P: O modernismo dá-se em momentos diferentes da história dos dois países: o Brasil dá-se conta da sua dimensão e potência enquanto Portugal, ex-império, ajusta-se à sua pequenez forçado pela ferida exposta do Ultimatum. Portugal precisa de aprender a gerir o passado enquanto o Brasil percebe-se como "país do futuro". Que consequências esta diferença de "tempos" teve para cada um dos movimentos?

Eduardo Lourenço: Não é de excluir que as expressões culturais que nós chamamos "modernismo", em Portugal e no Brasil relevem de "tempos" históricos diversos. Em Portugal no que, retrospectivamente, adquiriu um perfil mítico, digamos "depressivo" em termos de autoestima nacional (Ultramarina) e no Brasil de um tempo euforizante ou percebido como de "decolagem" em relação ao mais arcaizante e ainda pouco europeu, do Império dos primeiros anos da República. Contudo, isso nem explica que a ambos os "movimentos" se aplique o mesmo conceito (como aliás se aplicou antes em Espanha e não revela da mesma vontade "revolucionária", quer dizer, de ruptura clamorosa com a poesia anterior), nem que a analogia da designação incite a aproximar "o modernismo" português e o "modernismo" brasileiro. Mais interessante me parece sublinhar em que é que ambos são diferentes e só por analogia extrínseca, expressões de uma mesma ou virtual modernidade.

O "modernismo" português é "futurante", é revolucionário na forma como "sensacionismo" e "futurismo", mas simbolista e ultrassimbolista na visão e no fundo. Não tem leitura fora da revolução poética que vai de Baudelaire ao Futurismo, passando por Mallarmé. E em si nada tem de "nacionalista" no sentido tradicional do termo. O nosso "modernismo" é, ideologicamente, equívoco e complexo, mas pouco tem que ver com o "progressismo" político e social de que a então jovem República se queria exemplo, em oposição ao "ancient règime" monárquico. O nosso "modernismo" oscila entre uma nostalgia intemporal de paraísos perdidos ou futuros (Pessoa) e a celebração dos tempos novos de beleza e fascínio desconhecidos dos antigos. Parece-me que o "modernismo" brasileiro releva de um "voluntarismo" e um radicalismo tipicamente provocatórios, de essência antieuropeia, destinados a pôr o Brasil e a sua cultura idealmente no ponto zero da sua História. O "modernismo" brasileiro foi (na medida do possível) a verdadeira carta de Vaz de Caminha. O famigerado canibalismo cultural exemplificado pela exaltação da antropofagia, mesmo contando com o humorismo da atitude, traduz bem a essência do "modernismo" brasileiro, que não tinha milhares de anos para rejeitar, mas apenas uma cultura herdada de Portugal e só com excepção comparável com ela. Só a língua escapou a esta vontade de "regresso" a origens que nunca existiram (salvo a índia) mas a vontade de se separar dela ou de a renovar a fundo, e o que trouxe consigo, "performances" indiscutíveis (Oswald, Mário de Andrade) - basta para separar a pulsão do nosso "modernismo" da do "modernismo" brasileiro. 


\section{MODERNISMO PORTUGUÊS, MODERNISMO BRASILEIRO}

P: Segundo a sua opinião, o que caracteriza o modernismo brasileiro, e se constitui como "segunda natureza do Brasil", é a sua "estrutura cultural eufórica”. Trata-se da mesma percepção que tem Antonio Candido ao afirmar que a originalidade do modernismo brasileiro foi o seu sentimento de triunfo, relacionado com a libertação de uma série de recalques históricos, sociais e étnicos trazidos à tona da consciência literária e convertidos em superioridades. Os dois concordam que a partir desse momento se dá uma profunda alteração na relação entre os dois países, mas diferem na opinião que têm dela: se para si se trata de uma rasura - o Brasil "rejeitava com a água do banho a criança colonial e escrava que fora durante séculos" (LOURENÇO, 2001, p. 201) -, Antonio Candido vê aí o "fim da posição de inferioridade no diálogo secular com Portugal" (CANDIDO, 1976, p. 119), marca da originalidade do modernismo brasileiro. O que pensa da opinião de Antonio Candido?

EL: Na resposta à primeira questão já disse o essencial. Creio que as nossas duas opiniões acerca do modernismo brasileiro (a de Antonio Candido e a minha) não são inconciliáveis. Como português, sublinhei a "morte do pai" que para mim representou, mas compreendo que é uma "dor de pai" (abusivo) a que se exprime ainda nesse diagnóstico que merece ser aprofundado. Antonio Candido terá razão em ver nele o "o fim da posição de inferioridade cultural" representado pelos brasileiros em relação à herança cultural. Só os brasileiros são "sujeitos" dessa opinião e por isso "actores" de uma rejeição ou reivindicação de igualdade cultural que, vendo bem, nunca ninguém lhes negou. De que "inferioridade cultural" no diálogo (raro, mas real) com Portugal se podia queixar um Machado de Assis? E hoje, da admiração incondicional que nos merecem os Guimarães Rosa, as Clarice Lispector, os Carlos Drummond de Andrade etc?

\section{APESAR DO "DIVÓRCIO MODERNISTA"}

P: Há uma corrente pró-lusitanista que se desenvolve a partir da geração de 30, principalmente com Gilberto Freyre. O próprio Oswald de Andrade, em seus últimos textos, faz a defesa da colonização portuguesa em comparação à inglesa ocorrida nos Estados Unidos: "aqui não sofremos ainda a interferência deformadora dos grandes parvenus da era da máquina. Ao contrário, entre nós alastrou-se e criou raízes em coordenadas de superior inteligência humana, a característica civilização luso-tropical que nos ensinou a igualdade prática das raças e boa vontade como elo do trabalho, da cooperação e da vida." (ANDRADE, 1991, p.73) Não é curioso que tanto o Oswald tardio como Gilberto Freyre sejam autores mal vistos pelo pensamento uspiano? 
EL: Conheço mal essa querela brasílica - brasileira, mas parece-me significativa. Na "invenção" do Brasil, - uma vez levada a cabo - mesmo o passado que foi necessário "matar" para readiquirir o estatuto da modernidade plena, seria fatal que o recalcado, pelo nacionalismo modernista, viesse um dia a ser reivindicado. Tanto pior para a USP...

\section{BRASIL E O REDESCOBRIMENTO}

P: Em 2000, quando se comemoraram os 500 anos do descobrimento do Brasil, o nome escolhido para a série de eventos Brasil afora foi "BRASIL + 500 ANOS A mostra do redescobrimento". O nome diz tudo: O Brasil, que não comemora a sua descoberta, país sem pai, sem presente nem passado, em perpétuo começar. Curiosamente, as comemorações da chegada da corte ao Brasil, em 2008, estão a ser tratadas com grande entusiasmo e empenho pelo governo brasileiro. Estará o Brasil a caminho de rever a rasura de Portugal no seu imaginário? Será ele decorrência do movimento maior de revisão da história a que agora se assiste, em que se discute a integração efetiva de outros grupos sociais como o negro e o índio?

ED: Já em tempos comentei o "impasse” brasileiro por ocasião das (não) comemorações da Descoberta. Mudam-se os tempos...

O que é novo é que o Brasil (que emigra) descobre o antigo ninho fraterno em nós. É um progresso. Creio que com o tempo o Brasil nos "integrará". Nos "saudará": eles integrarão o "tempo português" deles e nós o brasileiro, deles e nosso...AMÉM!

Vence, 20 de fevereiro de 2007

\section{REFERÊNCIAS BIBLIOGRÁFICAS}

ANDRADE, Oswald de. Ponta de lança. São Paulo: Editora Globo, 1991.

LOURENÇO, Eduardo. A nau de Ícaro. São Paulo: Companhia das Letras, 2001.

CANDIDO, Antonio. Literatura e sociedade. Estudos de teoria e história literária. Companhia Editora Nacional, 1976.

Recebido para publicação em 29/11/14

Aprovado em 10/02/15 